\title{
Factors driving the biogeographic distribution of two temperate Australian damselfishes and ramifications for range shifts
}

\author{
Ronen Galaiduk $^{1, *}$, Will F. Figueira ${ }^{1,2}$, Michael J. Kingsford ${ }^{3}$, Belinda G. Curley ${ }^{2}$ \\ ${ }^{1}$ School of Biological Sciences, Marine Ecology Laboratories, A11, University of Sydney, New South Wales 2006, Australia \\ ${ }^{2}$ Sydney Institute of Marine Science, Building 22, Chowder Bay Road, Mosman, New South Wales 2088, Australia \\ ${ }^{3}$ School of Marine and Tropical Biology and ARC Centre of Excellence for Coral Reef Studies, James Cook University, \\ Queensland 4811, Australia
}

\begin{abstract}
The distribution and abundance of marine organisms is determined by interactions among numerous abiotic and biotic factors that operate across multiple spatial scales. This study focused on 2 endemic temperate damselfishes Parma microlepis and P. unifasciata, which have a similar ecology but only partially overlapping $\left(\sim 3^{\circ}\right.$ of latitude) biogeographical and depth ranges. The synergistic effects of temperature, competition and habitat use on patterns of abundance, distribution and growth were investigated using a combination of mensurative and manipulative field and laboratory experiments. Evidence suggests that the current ranges of both species are driven largely by latitudinal and depth variations in habitat types and not by thermal regimes. P. microlepis was shown to be a slower-growing, long-lived species (to $37 \mathrm{yr}$ ) that appears to be specialised in using urchin-grazed barrens. In contrast, $P$. unifasciata is a shorter-lived species (to $12 \mathrm{yr}$ ) and more of a habitat generalist. Where the ranges of these 2 species overlap, competitive interactions appear to drive patterns of habitat use, with $P$. microlepis potentially excluding $P$. unifasciata from urchin-grazed barrens habitat. Mesocosm laboratory experiments indicated that the outcome of competitive interactions between these 2 species is temperature-dependent, with $P$. microlepis dominance increasing at higher temperatures. This study clarifies the important role of habitat in determining latitudinal ranges of these 2 species. It also highlights the need to consider temperature-dependent behavioural interactions to properly understand future potential shifts in species ranges that may result from global climate change.
\end{abstract}

KEY WORDS: Damselfishes - Parma microlepis - Parma unifasciata - Biological distribution · Range expansion $\cdot$ Global warming

Resale or republication not permitted without written consent of the publisher

\section{INTRODUCTION}

Global warming and associated increases in sea surface temperature (SST) will result in southern biogeographical range shifts for many marine species (IPCC 2007, Poloczanska et al. 2007). Where an organism's life history provides a mechanism for movement (as with the pelagic larval phase of many marine species), the potential for range shifts in response to this warming is high. Despite this, our ability to predict the timing and extent of such range shifts is ultimately limited by our understanding of the complex interactions among biotic and abiotic factors in these systems that affect both the pre- and post-settlement processes (Tait 1981, Jones 1984a,b, Choat \& Ayling 1987, Holbrook et al. 1990, Holbrook et al. 1994). Previous research has demonstrated that factors such as (but not limited to) temperature (Ling et al. 2009a, Figueira \& Booth 2010, Last et al. 2011), habitat type and quality (Jones 1984c, Kingsford et al. 1989, Curley et al. 2002), competition and predation (Harrington \& Losey 1990, Hixon \& Jones 2005, 
Figueira et al. 2009) are key drivers of local demographic rates in coastal marine systems and thus their interaction will ultimately determine the extent of biogeographic ranges.

On a very broad spatial scale, the range of a species will be influenced by temperature due to physiological constraints on different life-history stages (Angilletta et al. 2002, Munday et al. 2008a). Within the range of tolerance, variation in temperature can influence growth (Jobling 1997, Hurst 2007), reproduction (Roessig et al. 2004, Helmuth et al. 2005) and behavioural interactions (Figueira et al. 2009, Biro et al. 2010) of individuals. For example, elevated temperatures may accelerate larval growth and development in tropical fishes, thereby altering the optimal conditions for survival and dispersal of larvae (Edwards \& Richardson 2004, Gagliano et al. 2007). In addition, elevated temperatures can increase individual fish activity levels, which can lead to greater predation mortality due to greater visibility to and encounter rates with predators (Biro et al. 2007). As a result of the combined influence of temperature on all of these important life-history processes, the distributional range of marine species is often dictated by their thermal environment (Walther et al. 2002, Keser et al. 2005, Perry et al. 2005).

The distribution and abundance of tropical and temperate fishes have been shown to be affected by aspects of habitat, such as the type of habitat, its distribution and variation in its biological and physical properties (e.g. depth, wave exposure, cover of macroalgae; Choat \& Ayling 1987, Kingsford et al. 1989, Holbrook et al. 1994, Gillanders \& Kingsford 1998, Curley et al. 2002, Kingsford \& Carlson 2010). In addition, marine habitats provide various resources for fishes including food, shelter and spawning sites (Moran \& Sale 1977, Sale 1978a, Tzioumis \& Kingsford 1995). Thus, habitat loss has a major effect on fish species diversity. Such effects are likely to be at least as important as direct climate change effects on temperate fishes (Booth et al. 2009). Variation in abundance due to habitat dependence is most obvious for habitat specialists that have low resistance to, and resilience for, changes in habitat properties (Kingsford \& Carlson 2010). Such changes can lead to localised extinction (Jones et al. 2004) or reduced growth rates (Pratchett et al. 2004, Feary 2007) for habitat-specialist species. However, it is not only habitat specialists that will be affected by global warming. Dramatic changes in habitat quality or structure could similarly affect more resistant habitat-generalist species (Feary 2007, Ling 2008).
In addition to temperature and habitat, biotic processes such as competition can influence the biogeographical range or abundance of species with similar ecological requirements (Hixon \& Jones 2005). Competition for a set of limited resources, is frequently observed among animals sharing the same habitat, where they compete for limited resources, such as food, space or shelter (Moran \& Sale 1977, Thompson \& Jones 1983, Fischer 2000). In the case of territorial fishes, occupants of high-quality territories can control food supplies or foraging opportunities, shelters from predators or suitable breeding areas (Connell 1961, Debenedictis 1974, Sale 1978b, Johnsson et al. 2000). In these situations, competition may reduce the growth rate, development or fecundity of individuals (Valiela 1995), thus potentially leaving them more vulnerable to predation (Jones 1986, Fischer 2000, Hixon \& Jones 2005).

Although knowledge of the role of individual biotic and abiotic factors is important, understanding the interactions among these factors is the key to accurately predicting potential changes in population dynamics. For example, abundances of habitat-modifying species that drive distributions can be closely tied to temperature (Last et al. 2011). Increases in water temperature are known to cause range contraction for some habitat-determining species, such as giant kelp (Johnson et al. 2011, Wernberg et al. 2011), or range expansion for other habitat-modifying species, such as sea urchins (Johnson et al. 2005, Ling 2008). Temperature may also affect the performance of a species and affect its ability to compete (Biro et al. 2010). In some cases, individuals can survive extremely low temperatures when other biological aspects, such as competition or predation, are not present (Figueira \& Booth 2010). However, competition can deny individuals' access to important resources such as shelter or food and by this reduce their physiological performance, exposing them to increased risk of predation or harmfully low temperatures. In addition, decreased physiological performance due to low temperature can similarly increase exposure to predation or weaken the competitive ability of individuals (Figueira et al. 2009).

In this study, we focus on developing a better understanding of the mechanisms that drive the latitudinal and depth ranges of 2 ecologically similar and partly sympatric congeneric damselfishes, Parma microlepis and P. unifasciata. While there are differences in the latitudinal and depth distributions of these otherwise relatively ecologically similar species (described in greater detail in 'Materials and methods: Study species and their distribution pat- 
terns' below), the role of various biotic and abiotic factors in driving these patterns remains unclear (Moran \& Sale 1977, Buckle \& Booth 2009). There are obvious differences in water temperatures across the latitudinal range of these 2 species, and thus differences in the optimal temperatures for growth, survival and reproduction may play a role in driving these patterns. However, changes in the occurrence of preferred habitats across this range, in conjunction with competitive interactions, may shape biogeographic and depth distributions to a greater extent than the direct effects of temperature. The overall aim of this study was to better understand the isolated and interactive effects of temperature, habitat distribution and interspecific competition in driving the latitudinal and depth distributions of P. microlepis and $P$. unifasciata along the southeastern coast of Australia. Our approach was to use a combination of field surveys and field and lab experiments to address the following questions: (1) Are distributions of occurrence influenced by habitat type, and are patterns consistent with latitude and/or depth? (2) Are there differences in temperature-dependent growth rates consistent with the latitudinal and depth distributions of these 2 species? (3) What are the outcomes of competitive interactions between the 2 species, and do they vary with water temperature? By answering these questions, we will be able to better understand the interactive effects of increasing ocean temperatures in the southeastern Australia region (due to increasing southern penetration of the East Australian Current [EAC]). Increasing ocean temperatures are paving the way for range expansions of many species of tropical and temperate fishes as far south as Tasmania (Booth et al. 2007, Poloczanska et al. 2007, Ridgway 2007a, Figueira \& Booth 2010, Last et al. 2011, Wernberg et al. 2011), directly via effects on growth and survival of the fish themselves or indirectly by effects on habitat-forming organisms, such as kelp, or important grazers, such as the sea urchin Centrostephanus rodgersii, which is the main architect of urchin-grazed barrens habitat (hereafter urchin barrens) in this region.

\section{MATERIALS AND METHODS}

\section{Study species and their distribution patterns}

Parma microlepis (white-eared parma) and P. unifasciata (girdled parma) are congeneric damselfishes (family: Pomacentridae) endemic to the east coast of Australia. The average winter water temperatures experienced by the species within their biogeographical range (about $15^{\circ}$ of latitude) are between 14 and $22^{\circ} \mathrm{C}$. P. microlepis is long-lived, known to reach $37 \mathrm{yr}$ of age, and is one of the most abundant reef fishes in New South Wales (NSW), residing predominantly in urchin barrens (Tzioumis \& Kingsford 1995, Curley et al. 2002). P. microlepis occurs over a wide range of depths from 2 to $40 \mathrm{~m}$ but is most common between 3 and $15 \mathrm{~m}$ in the southern half of NSW and into Victoria (range 32 to $42^{\circ} \mathrm{S}$, mode around $35^{\circ} \mathrm{S}$; Kingsford \& Battershill 1998, Reef Life Survey program, see Edgar \& Stuart-Smith 2009 for detailed methods). Adult fishes are predominantly herbivorous, with a diet of 73 to $85 \%$ plant material (Moran \& Sale 1977, Buckle \& Booth 2009). In contrast to $P$. microlepis, the ecology of $P$. unifasciata is poorly studied. Maximum age and habitat preferences had not been quantified until this study, though adults have a diet quite similar to $P$. microlepis, consisting of $95 \%$ plant material (Buckle \& Booth 2009). Unlike $P$. microlepis, $P$. unifasciata is more abundant in the northern half of NSW (range from $27^{\circ} \mathrm{S}$ to $37^{\circ} \mathrm{S}$, mode around $31^{\circ} \mathrm{S}$ at Southwest Rocks; Reef Life Survey program, Malcolm et al. 2007). Both species maintain and protect permanent territories and cooccur on reefs in the Sydney region, where they may use the same habitat type and compete with one another for shelter (Moran \& Sale 1977, Curley et al. 2002). In addition, despite the strong ecological similarities between the 2 species, when they co-occur, $P$. unifasciata tends to be more abundant in shallower water than $P$. microlepis and is rarely observed deeper than $12 \mathrm{~m}$ (Buckle \& Booth 2009).

\section{Distribution and habitat associations}

We evaluated patterns of the latitudinal distribution and habitat association of the 2 study species using replicated habitat-specific underwater visual census surveys on SCUBA at 2 or more sites (separated by hundreds of metres to kilometres) at 15 locations (mainland and some island sites: Solitary Islands $29^{\circ} \mathrm{S}$, Wollongong Islands $34.5^{\circ} \mathrm{S}$, Montague Island $36.2^{\circ} \mathrm{S}$, Gabo Island $38^{\circ} \mathrm{S}$ ) along the coast of NSW and into northern Victoria $\left(29^{\circ} \mathrm{S}\right.$ to $38^{\circ} \mathrm{S}$; Fig. 1). Surveys were done during the austral summer and spring of 1988. At each site, all juveniles (based on coloration) and adults of both species were counted in each habitat type that occurred within a depth range of 3 to $25 \mathrm{~m}$ when water visibility was greater than $5 \mathrm{~m}$. The availability of habitat was defined as the presence of a habitat type (after an 


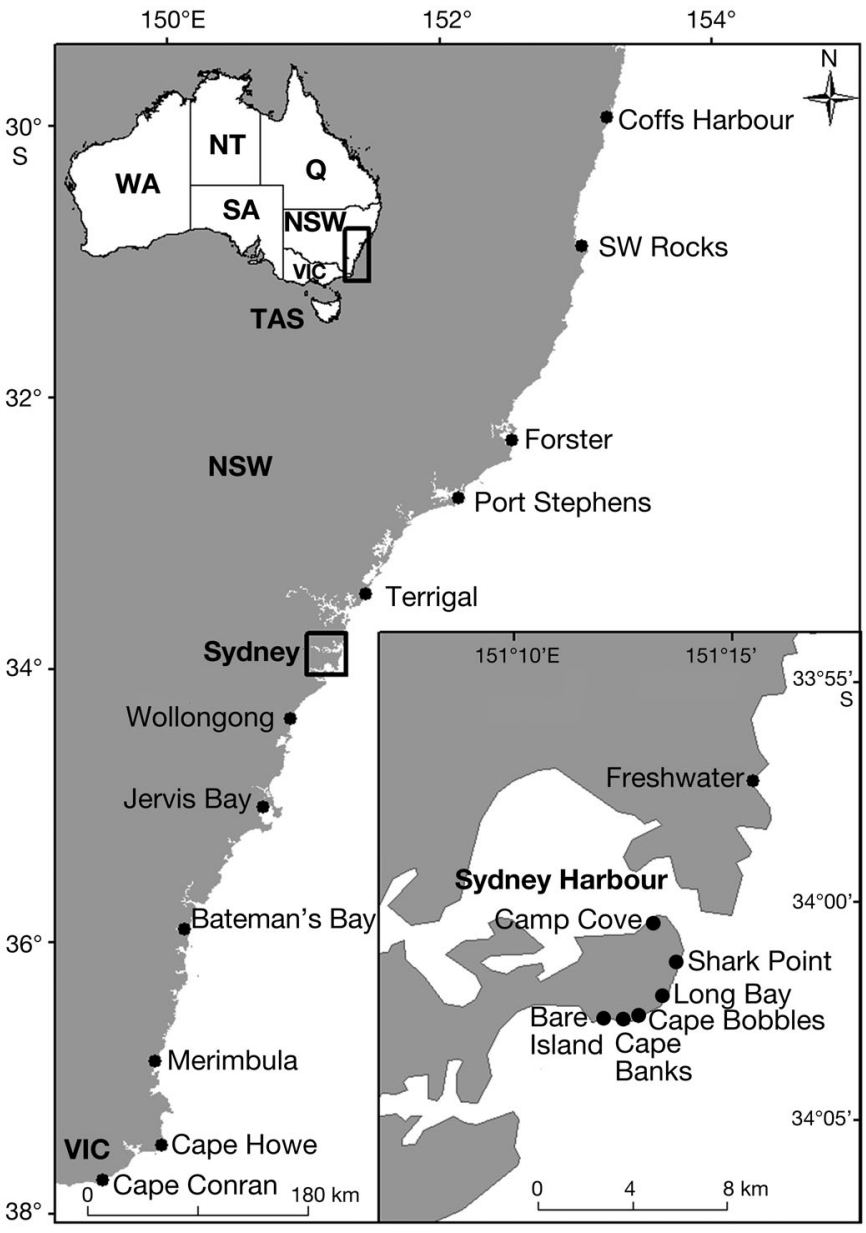

Fig. 1. Coast of New South Wales and northern Victoria, Australia, showing locations of the abundance-related surveys and fish collection sites (coordinates for island sites are given in the text; inset: enlargement of the Sydney area)

extensive search of the site) that allowed for 6 replicate $25 \times 5 \mathrm{~m}$ transects. This approach gives a clear indication of changes in the presence of dominant subtidal habitats versus density of fishes across latitudes. In total, 7 habitat types were identified: shallows, fringe, Phyllospora comosa and Ecklonia radiata forests, ascidian-dominated reef (Pyura), urchin barrens, mixture of E. radiata and urchin barrens, and deep reef (sensu Underwood et al. 1991, Kingsford \& Carlson 2010). Statistical comparisons of habitat versus species density were not viable across the entire latitudinal range due to lack of similar habitats and/or presence of both species at all sites. As such, we identified 2 sites (Cape Banks and Cape Bobbles) in the Sydney region (where species' distributions overlapped) at which the 5 most common habitats could be found (shallows, fringe, urchin barrens, E. radiata kelp forest and deep reef). We repeated surveys using the above methodology, allowing for a full orthogonal cross of species, size and habitat in this region of co-occurrence.

Latitudinal trends of habitat availability and occupancy were evaluated by assessing the average density (across all transects) of each species in each habitat present at each site across the range. Total counts of individuals of each species were presented as percentages observed in each habitat type versus overall habitat availability. Differences in the density of adult and juvenile fish of each species in each of the 5 habitat types around the Sydney region where they co-occur were evaluated using ANOVA, with 'habitat' and 'size' being 2 fixed factors. As we were most interested in evaluating relative patterns of habitat use by juveniles and adults of each species rather than comparisons of absolute densities of either species in specific habitats or size classes, we analysed each species separately. Data were $\log _{10}$ transformed prior to analysis to meet assumptions of homogeneity of variance (based on Cochran's test results). Even after transformation, the data were heterogeneous, but for analyses with large sample sizes (as in this study), ANOVA is robust to violation of the assumption of homogeneity (Underwood 1997), so we proceeded with analyses on transformed data. Tukey's post hoc tests were used to assess differences between the abundance of adults and juveniles of the study species in various habitats.

\section{Effect of temperature on growth}

It was hypothesised that if water temperature uniquely drives the distributional patterns (latitude and/or depth) of these 2 species, we would see differences between the species in the optimal temperatures for important performance metrics, such as growth, as well as possible differences in natural growth rates for fish occurring at different temperatures. We evaluated thermal performance curves using controlled temperature-growth experiments in the lab and estimated natural growth rate-temperature interactions for each species by ageing (using otoliths) fish from different sites and depths around Sydney.

Controlled-temperature lab experiments were conducted in 2 semi-recirculating seawater systems (system volume refreshed approximately once per day) equipped with mechanical filtration (to $10 \mu \mathrm{m}$ ), UV sterilization and heater/chiller units for temperature control at the Sydney Institute of Marine Science (SIMS) from June to September of 2010. 
Individuals of Parma microlepis and P. unifasciata (juveniles of 45 to $100 \mathrm{~mm}$ total length, TL) were collected from rocky reef habitat at Long Bay and Freshwater in Sydney (Fig. 1) using hand nets and clove oil anaesthetic (5\% clove oil in ethanol) on SCUBA. Fishes were transferred in aerated buckets to SIMS and held individually in subdivided (in thirds) 451 opaque-walled tubs with flow rates of $>10 \mathrm{l} \mathrm{h}^{-1}$. Each section contained PVC tubing for shelter. For the first $10 \mathrm{~d}$, fishes were acclimated to captivity in ambient water of $19^{\circ} \mathrm{C}$; afterwards, they were randomly assigned and gradually (at no more than $1^{\circ} \mathrm{C}$ per $24 \mathrm{~h}$ ) acclimated to one of the 4 different temperature treatments typical of temperatures found across the range of both of these species: $13,17,21$ and $25^{\circ} \mathrm{C}$. For each treatment, there were 6 individuals of each species. Fish were fed daily to satiation with Spectrum regular formula fish food for the whole period of the experiment ( $6 \mathrm{wk}$ ). This formula contained a mix of foods which did not exclude omnivorous or herbivorous fishes and was unlikely to affect relative patterns investigated; however, it was most likely to deviate from the natural diet of both species. Once accustomed to the tanks, the individuals ate food pellets readily. Fish size and mass were monitored on an approximately weekly basis by removing fish from tubs and measuring total and standard length (SL) (to the nearest $0.1 \mathrm{~mm}$ with callipers) and wet mass (to the nearest $0.01 \mathrm{~g}$ ). To avoid bias from the specific location of the fish in holding tubs, the individuals were rotated between the holding compartments after measurements were taken. Instantaneous growth $\left(G_{\text {inst }}\right)$ was calculated from changes in mass over the midpoint of the holding period, Weeks 2 to 4 $\left(M_{1}\right.$ and $M_{2}$, respectively; $\Delta t=$ days between readings), across all temperature treatments (Figueira et al. 2009):

$$
G_{\text {inst }}=\frac{\ln \left(\frac{M_{2}}{M_{1}}\right)}{\Delta t}
$$

We assessed any differential effects of temperature on growth rates between the 2 species using ANOVA, where $G_{\text {inst }}$ growth was used as the response variable, and species and temperature were fixed factors. Data were rank-transformed prior to the analysis to meet assumptions of homogeneity of variance (based on Cochran's test results) and to avoid negative values in cases where the fish lost weight $(43 \%$ of observations).

Natural growth rates of fishes from different sites (Freshwater, Terrigal and Bare Island [Parma microlepis only, as $P$. unifasciata is quite rare at this site]) and depths (shallow $=0$ to $4 \mathrm{~m}$, deep $=12$ to $14 \mathrm{~m}$ ) around the Sydney region were determined for fishes collected with hand spears, as well as all fishes euthanized at the end of the temperature-controlled lab experiments (described above). All fishes were weighed to the nearest $0.01 \mathrm{~g}$, their SL and TL recorded to the nearest $0.1 \mathrm{~mm}$ and sagittal otoliths extracted. Both otoliths (left and right) were washed with deionised water to remove flesh and left to dry overnight, after which they were weighed to the nearest $0.1 \mathrm{mg}$. Only left otoliths were used for ageing. In cases where the left otolith was missing or completely shattered, it was replaced by the right otolith (6.8\% of all cases). Fish ageing was performed following the protocol of Kesby \& McKinnon (2009), which involved reading annual rings from a polished transverse section of each otolith. We conducted independent blind counts of each otolith on 2 separate occasions. When counts were the same or within 1 increment of each other, we kept the original value (92.5\% of the time). When counts varied by a value greater than 2, increments were recounted. If agreement between readings was not obtained with this additional count and the 3 readings gave consecutive estimates of age, the median count was used for the age of that fish $(2.5 \%)$. Age of fish younger than $1 \mathrm{yr}$ was estimated as their proportional TL compared to that of the largest sub-1-yr-old in the dataset for a given species. Rings have been validated as annual for P. microlepis (see Tzioumis \& Kingsford 1995 for methods) but not for P. unifasciata. Estimates of size at age were fitted to the von Bertalanffy growth function with a least squares loss function:

$$
L_{t}=L_{\infty}\left(1-\mathrm{e}^{-K\left(t-t_{0}\right)}\right)
$$

where $L_{t}=$ length at age $t_{1} L_{\infty}=$ asymptotic length, $K=$ growth coefficient and $t_{0}=$ constrained age to a size at hatching (in this case, a hypothetical length of $3 \mathrm{~mm}$ ). Comparisons of growth rates among species and depths (sample sizes were too low for site-level comparisons) were made using $L_{\infty}$ versus $K$ plots with calculated 95\% confidence regions (Kimura 1980, Kritzer 2002). As fitted values depend on the value of $t_{0}$, to compare different curves, we used a common $t_{0}$ value of $-0.03 \mathrm{yr}$ in all model fits, which was derived from the best-fit model for all data combined (see Kimura 1980, Kritzer 2002).

\section{Competitive interactions and temperature}

While the above methods addressed the roles of habitat and temperature in determining the largescale distribution of these 2 species, in regions where 


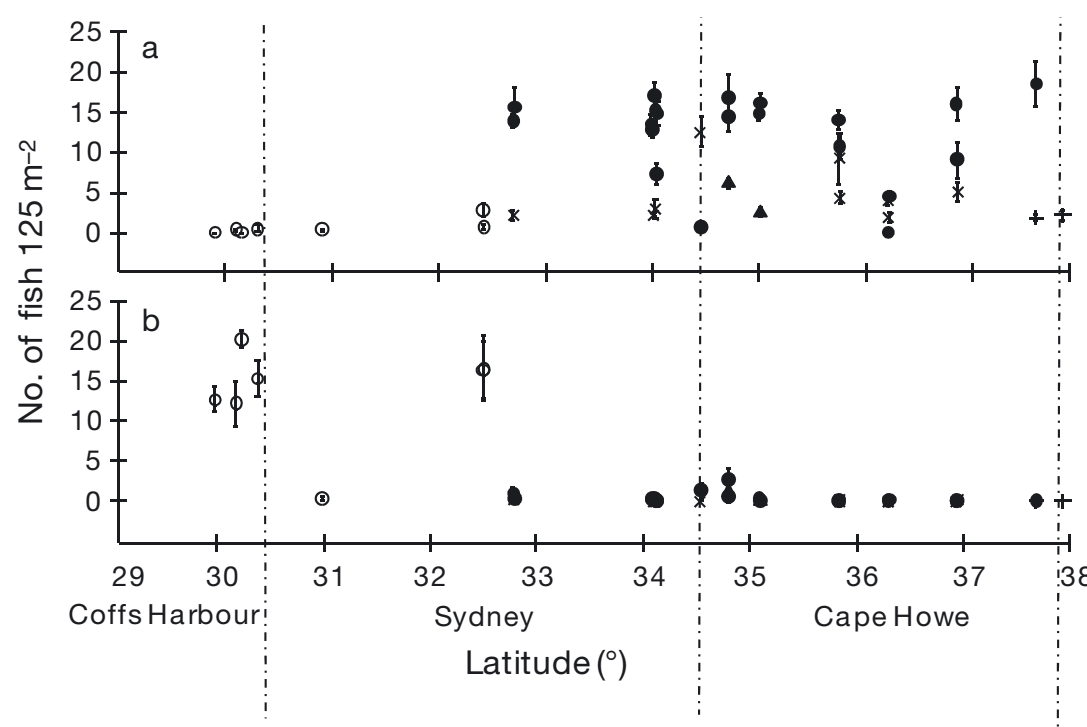

Fig. 2. Parma unifasciata and P. microlepis. Habitat-related species density $( \pm \mathrm{SE})$ of (a) $P$. microlepis and (b) $P$. unifasciata along the southeastern coast of Australia. (O) ascidian-dominated reef, (•) urchin barrens, $(\times)$ kelp forest (Ecklonia radiata),(ム) urchin barrens and kelp forest, (+) Phyllospora comosa with the distance reduced every $30 \mathrm{~s}$ by large intervals initially $(50 \mathrm{~cm})$ and smaller intervals $(5 \mathrm{~cm})$ once the focal fish became obviously vigilant. The presentation was terminated when the focal fish attacked the presented container or if the initial location of the focal fish was reached without attack. The exact distance between the initial location of the focal fish and the final location of the stimuli fish was then recorded. Six replicate trials were conducted for each treatment block. Analysis was restricted to data for focal fish larger than $120 \mathrm{~mm}$, as only this group expressed any aggressive behaviour in the trials; no fish attacked the control container.

The effects of focal and stimuli fish species and size of stimuli fish on maximum attack distance were assessed with a 3 factor repeated-mea- they co-occur (such as Sydney), the outcomes of competitive interactions among these territorial fishes are also likely to be dictating patterns of habitat and/or depth occupancy. We therefore evaluated the relative aggression of each species within the Sydney region by quantifying relative territoriality of wild fish in situ. Working under the hypothesis that the performance of each species may be linked to different thermal optima, we then looked at the potential role of temperature in mitigating the outcome of direct competitive interactions using mesocosm lab studies.

Territoriality was quantified by a field experiment conducted at Long Bay during the months of July and August 2010. The experiment involved presenting randomly chosen focal fish in 3 size classes (smaller than $90 \mathrm{~mm}, 90$ to $110 \mathrm{~mm}$ and greater than $120 \mathrm{~mm}$ TL) of both species with 2 different-sized (90 to $100 \mathrm{~mm}$ and 110 to $120 \mathrm{~mm}$ ) stimuli fish of each species and an empty control container to determine their maximum distance to attack stimuli fish (Altmann 1974, Moran \& Sale 1977). Stimuli fishes were collected as described above and transferred into a transparent presentation container. Due to the timeconsuming process of stimuli fishes collection, the same stimuli fish were used for all the experiments. A focal fish was randomly chosen and, following a $2 \mathrm{~min}$ acclimation period, was presented with all stimuli fishes and a control container in series (random order) with roughly 5 min between presentations. Each presentation was initiated $4 \mathrm{~m}$ from the focal fish, sures ANOVA with 1 between-subjects fixed factor (focal fish species, 2 levels) and 2 within-subjects factors (stimuli fish species, 2 levels; and stimuli fish size, 2 levels). Data were rank transformed prior to testing to meet assumption of homogeneity of variance (Cochran's test). Where interactive effects were present, Tukey's post hoc tests were used to assess differences between various levels of factors.

The effect of temperature on competitive outcomes was tested using fishes from the laboratory growth studies, described above. After the acclimation period, 2 fishes of different species were moved from their individual holding tubs and placed on each side of a barrier which equally divided a $45 \mathrm{l}$ opaque walled tub and had 1 piece of PVC pipe for shelter. Their sizes were matched within the limits of using each fish only once for the independence of data, typically within $4 \mathrm{~mm}$ ( 5 to $11 \%$ of TL). After a 2 min acclimation period, the barrier was removed and fish were observed for $10 \mathrm{~min}$. Pilot studies indicated that one fish always exhibited clearly dominant behaviour (occupying shelter, continually chasing the other fish) within $10 \mathrm{~min}$. Thus, at the end of the observation period, the dominant fish was recorded and both fishes were returned to their original holding tubs. This experiment was performed at the same temperature treatments $\left(13,17,19,21\right.$ and $\left.25^{\circ} \mathrm{C}\right)$ as the controlled lab growth studies. The effect of temperature on the number of wins by each species was assessed with a Chi-square contingency table analysis. 


\section{RESULTS}

\section{Distribution and habitat associations}

Parma microlepis occurred primarily in either urchin barrens habitat $(89.2 \%)$ or within small bare patches among kelp (7.5\%) and mixed barrens/kelp $(1.8 \%)$ habitats, which occurred predominantly from the Sydney area $\left(33^{\circ} \mathrm{S}\right)$ south to Victoria $\left(38^{\circ} \mathrm{S}\right.$; Fig. 2). Urchin barrens is a very common habitat in this region but is largely absent north of $31^{\circ} \mathrm{S}$ (Fig. 2). In contrast, the distribution of $P$. unifasciata, which was found largely to the north of $32^{\circ} \mathrm{S}$, was slightly less temperate than that of $P$. microlepis. This species was mostly found in ascidian-dominated reef $(88.5 \%)$, which is rare south of about $33^{\circ} \mathrm{S}$ (Fig. 2). They were observed in a shallow urchin barrens habitat (10\%) around Sydney but were rare to $36^{\circ} \mathrm{S}$ and were not seen further south (Fig. 2). Within the Sydney region $\left(34^{\circ} \mathrm{S}\right)$, where both species occurred, there were strong interactions between habitat and size in the ANOVA models for each species (Table 1). Post hoc comparisons indicated that adult P. microlepis were significantly more abundant in urchin barrens and deep reef habitats (all $p \leq 0.009$ ), and these 2 habitats were significantly different from each other $(\mathrm{p}=$ 0.009 ; Fig. 3). The abundance of adult $P$. microlepis in kelp habitat was not significantly different from abundance in shallows and fringe habitats $(p \geq 0.07)$. However, the abundance of $P$. microlepis in the 2 latter habitats was significantly different from each other $(\mathrm{p}<0.0001)$. The abundance of juvenile $P$. microlepis was significantly lower than the abundance of adults of this species (all $p<0.01$ ) in all surveyed habitats, except that the abundance of juveniles of this species in fringe and deep reef habitats was not significantly different from the abundance of adults in shallows, fringe and kelp habitats (all $\mathrm{p}>0.2$ ). The abundance of juvenile $P$. microlepis in urchin barrens habitat was not significantly different from the abun-

Table 1. Parma unifasciata and P. microlepis. ANOVA of habitat- and sizerelated abundance for the study species. ns: $p \geq 0.05 ;{ }^{*} p<0.05 ;{ }^{* *} p<0.01$; ${ }^{* * *} \mathrm{p}<0.001$

\begin{tabular}{|c|c|c|c|c|c|c|c|}
\hline \multirow[t]{2}{*}{ Factor } & \multirow[t]{2}{*}{ df } & \multicolumn{3}{|c|}{$-P$. unifasciata -} & \multicolumn{3}{|c|}{ P. microlepis -} \\
\hline & & MS & $F$ & $\mathrm{p}$ & MS & $F$ & $\mathrm{p}$ \\
\hline Habitat & 4 & 1.367750 & 38.9083 & $* * *$ & 4.40819 & 76.754 & *** \\
\hline Size & 1 & 1.068109 & 30.3844 & $* * *$ & 6.57423 & 114.468 & $* * *$ \\
\hline Habitat $\times$ Size & 4 & 0.395553 & 11.2523 & $* * *$ & 0.29606 & 5.155 & *** \\
\hline Error & 230 & 0.035153 & & & 0.05743 & & \\
\hline Total & 239 & & & & & & \\
\hline
\end{tabular}

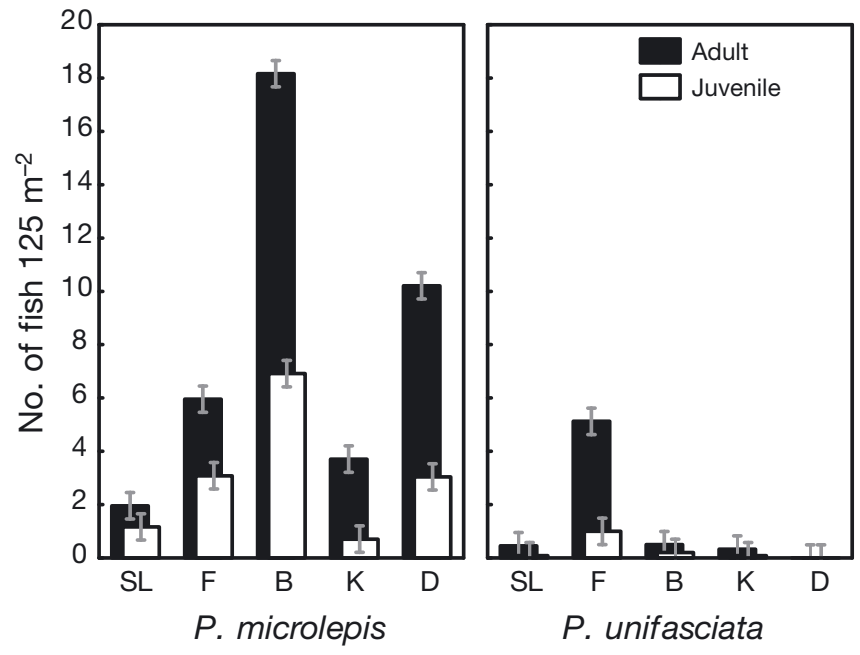

Fig. 3. Parma unifasciata and P. microlepis. Mean abundance $( \pm \mathrm{SE})$ among habitats from shallow water to deep reef: $\mathrm{SL}=$ shallows $(0$ to $2 \mathrm{~m}), \mathrm{F}=$ fringe $(1$ to $3 \mathrm{~m}), \mathrm{B}=$ urchin barrens ( 3 to $10 \mathrm{~m}), \mathrm{K}=$ Ecklonia radiata kelp forest ( 3 to $10 \mathrm{~m}), \mathrm{D}=$ deep reef (12 to $35 \mathrm{~m})$

dance of adults in fringe $(\mathrm{p}=0.82)$ and deep reef $(\mathrm{p}=$ $0.9)$ habitats. The abundance of adults and juveniles of $P$. microlepis in shallows habitat was not significantly different from each other $(\mathrm{p}=0.84$; Fig. 3). Juvenile $P$. microlepis was most abundant in urchin barrens and occurred in lower densities in deep reef and fringe habitats (all $\mathrm{p}<0.001$ ). The abundance of juvenile $P$. microlepis was not significantly different in fringe and deep reef $(p=1)$ and shallows and kelp forest $(p=0.87$ ) habitats (Fig. 3). P. unifasciata, however, showed a very different distribution, with adults being most common in the fringe habitat, while in the remaining habitats, abundance was equal to or close to zero (all $\mathrm{p}<0.001$ ). The abundance of juvenile $P$. unifasciata was significantly different from the abundance of adults of this species in fringe $(p<$ $0.001)$ and deep reef $(p=0.002)$ habitats. The relative abundance of juvenile $P$. unifasciata across surveyed habitats was highest in the fringe habitat (all $\mathrm{p} \leq$ $0.05)$, except that the density of fish in urchin barrens was not significantly different from the fringe habitat $(\mathrm{p}=$ 0.23; Fig. 3).

\section{Effects of temperature on growth}

Results of the controlled-temperature growth experiment indicated that juvenile Parma unifasciata grew significantly faster $\left(G_{\text {inst }}=0.005 \mathrm{~d}^{-1}\right)$ than juvenile $P$. microlepis $\left(G_{\text {inst }}=\right.$ 
$0.0004 \mathrm{~d}^{-1}$ ). ANOVA indicated significant effects of the factor 'species' $\left(F_{1,40}=5.4, \mathrm{p}=0.025\right)$ and the factor 'temperature' $\left(F_{3,40}=13.6, \mathrm{p}<0.001\right)$ but no interaction between the 2 factors $\left(F_{3,40}=1.5, \mathrm{p}=0.2\right.$; Table 2). Post hoc comparisons indicated that $P$. microlepis grew fastest at $21^{\circ} \mathrm{C}$ (all $\mathrm{p} \leq 0.007$ ); however, there was no significant difference in growth between 17 and $21^{\circ} \mathrm{C}(\mathrm{p}=0.2$; Fig. 4$)$. The growth of juvenile $P$. microlepis was not significantly different between $13^{\circ} \mathrm{C}, 17^{\circ} \mathrm{C}$ and $25{ }^{\circ} \mathrm{C}$ (all $\mathrm{p} \geq 0.2$ ). The growth of juvenile $P$. unifasciata was not significantly different among various temperature treatments (all $\mathrm{p} \geq 0.2$ ). The only exception was between $21^{\circ} \mathrm{C}$ and $13^{\circ} \mathrm{C}$ treatments $(\mathrm{p}<0.001$; Fig. 4$)$.

The otolith growth studies indicated a maximum age of $12 \mathrm{yr}$ for Parma unifasciata and 32 yr for $P$. microlepis ( $\mathrm{n}=57$ and 99, respectively). The individuals of both species were generally smaller $(P$. unifasciata $L_{\infty}=162.1 \mathrm{~mm} ;$ P. microlepis $L_{\infty}=163.2 \mathrm{~mm}$ ) in shallow water less than $5 \mathrm{~m}$ (water depth) in comparison to the individuals from deep water (12 to $14 \mathrm{~m}_{;} P$. unifasciata $L_{\infty}=177.5 \mathrm{~mm}_{i} P$. microlepis $L_{\infty}=$ $175.9 \mathrm{~mm}$; Fig. 5a). The $L_{\infty}$ versus $K 95 \%$ confidence ellipses for each species overlapped, indicating that

Table 2. Parma unifasciata and P. microlepis. Temperaturecontrolled growth experiment PERMANOVA results. ns: $\mathrm{p} \geq 0.05 ;{ }^{*} \mathrm{p}<0.05 ;{ }^{* *} \mathrm{p}<0.01 ;{ }^{* * *} \mathrm{p}<0.001$

\begin{tabular}{|lcrrc|}
\hline Factor & df & \multicolumn{1}{c}{ MS } & \multicolumn{1}{c|}{$F$} & $\mathrm{p}$ \\
\hline Species & 1 & 546.75 & 5.3969 & $*$ \\
Temperature & 3 & 1382.89 & 13.6503 & ${ }^{* * *}$ \\
Spp $\times$ Temp & 3 & 154.75 & 1.5275 & $\mathrm{~ns}$ \\
Residual & 40 & 101.31 & & \\
Total & 47 & & & \\
\hline
\end{tabular}

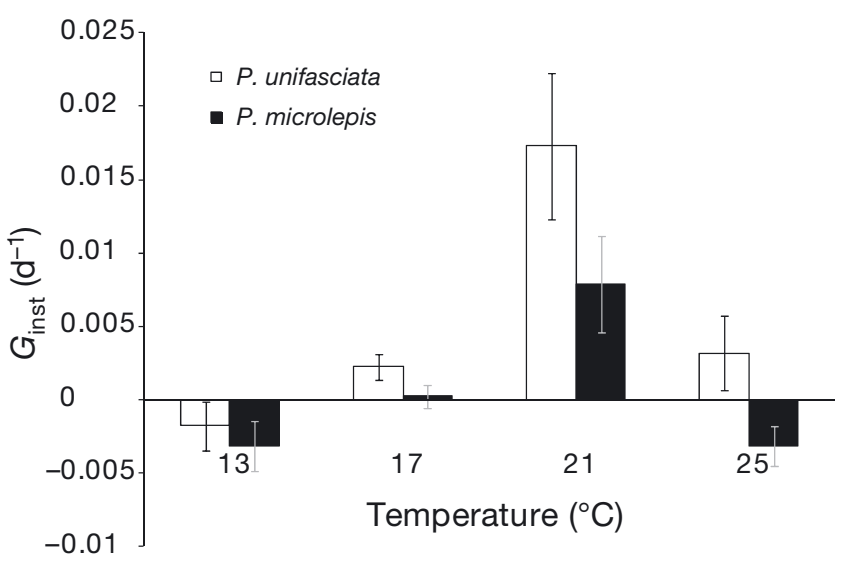

Fig. 4. Parma unifasciata and P. microlepis. Mean $( \pm \mathrm{SE})$ instantaneous growth $\left(G_{\text {inst }}\right)$ for 6 juvenile individuals of each species in 4 temperature treatments while both species had roughly similar maximum sizes ( $P$. unifasciata $L_{\infty}=169.7 \mathrm{~mm} ; P$. microlepis $L_{\infty}=$ $173.7 \mathrm{~mm}), P$. unifasciata had a higher growth rate $(P$. unifasciata $K=0.85$; $P$. microlepis $K=0.64$; Fig. 5b). The confidence ellipse was larger for $P$. unifasciata, due to its lower sample size.

\section{Competitive interactions and temperature}

The field experiment indicated that there was a significant interactive effect of the focal fish species with the size of the stimuli fish $\left(F_{1,10}=5.47, \mathrm{p}=0.04\right.$; Table 3). The effect was driven predominantly by the relatively greater aggression of Parma microlepis towards small stimuli of $P$. unifasciata or towards congener stimuli of either size, while $P$. unifasciata was most aggressive to large stimuli of $P$. microlepis (Fig. 6). Although Tukey's post hoc test revealed no significant difference (all $\mathrm{p} \geq 0.06$ ) among treatment blocks, there was a general trend of greater aggression by $P$. microlepis than by $P$. unifasciata.

In the temperature-controlled competition experiments, there was a significant effect of temperature on the number of wins by each species $\left(\chi^{2}=10.6, \mathrm{p}=\right.$ 0.03 ; Fig. 7). At $13^{\circ} \mathrm{C}$, each species won $50 \%$ of the trials $(\mathrm{n}=6)$, and at 17 and $19^{\circ} \mathrm{C}$, Parma unifasciata won $80 \%$ of the trials $(\mathrm{n}=5)$. At 21 and $25^{\circ} \mathrm{C}, P$. microlepis won $100 \%$ of the trials ( $\mathrm{n}=3$ and 4 , respectively).

\section{DISCUSSION}

Parma microlepis is a highly abundant member of temperate reef fish assemblages in the central-south-

Table 3. Parma unifasciata and P. microlepis. Effect of focal (Foc) and stimuli (St) fish species (spp.) and size of stimuli fish on maximum attack distance. ns: $p \geq 0.05 ;{ }^{*} p<0.05$

\begin{tabular}{|lrrcc|}
\hline Factor & df & MS & $F$ & $\mathrm{p}$ \\
\hline Focal spp. & 1 & 3250.52 & 6.48987 & $*$ \\
Error & 10 & 500.86 & & \\
Stimuli spp. & 1 & 123.52 & 4.16216 & $\mathrm{~ns}$ \\
St spp. × Foc spp. & 1 & 0.33 & 0.01123 & $\mathrm{~ns}$ \\
Error & 10 & 29.68 & & \\
St size & 1 & 3.00 & 0.22624 & $\mathrm{~ns}$ \\
St size $\times$ Foc spp. & 1 & 72.52 & 5.46897 & $*$ \\
Error & 10 & 13.26 & & \\
St spp. $\times$ St size & 1 & 13.02 & 1.78317 & $\mathrm{~ns}$ \\
St spp. $\times$ St size $\times$ Foc spp. & 1 & 0.08 & 0.01141 & $\mathrm{~ns}$ \\
Error & 10 & 7.30 & & \\
\hline
\end{tabular}




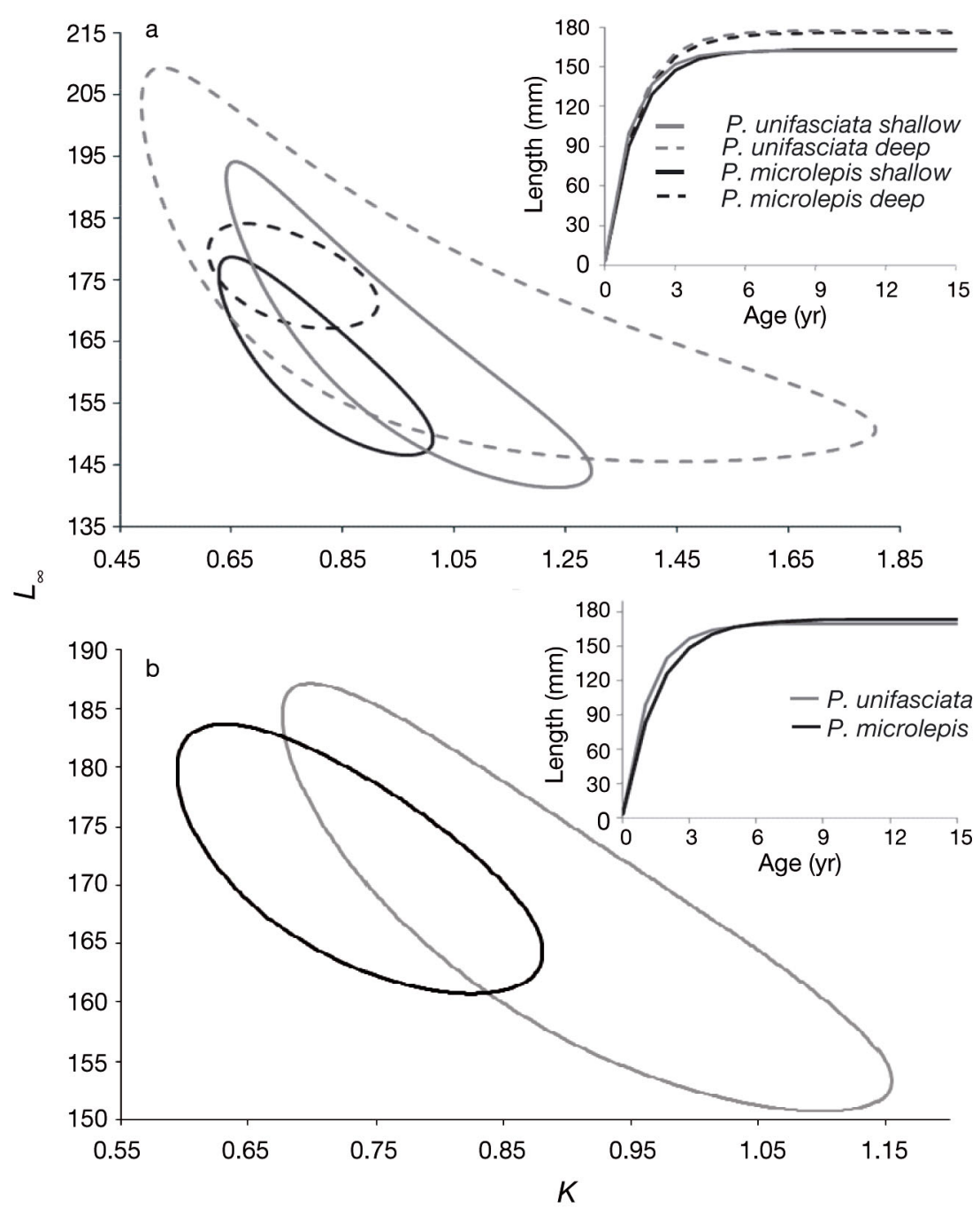

Fig. 5. Parma unifasciata and P. microlepis. Ninety-five percent joint confidence regions of the parameters $K$ and $L_{\infty}$ for both species (a) separated by collection depth-shallow $(<5 \mathrm{~m}) P$. unifasciata $(\mathrm{n}=41), P$. microlepis $(\mathrm{n}=56)$ and deep $(>12 \mathrm{~m})$ P. unifasciata $(\mathrm{n}=16)$, P. microlepis $(\mathrm{n}=43)$-and $(\mathrm{b})$ pooled across all depths of sampling for $P$. unifasciata $(\mathrm{n}=57)$ and $P$. microlepis ( $\mathrm{n}=99)$. Insets: predicted growth curves

cantly higher in urchin barrens than in any other habitat across all study sites. The only exception was the high abundance of this species in deep reef habitat. This habitat is very similar to urchin barrens, with low cover of tufting and kelp algae (Underwood et al. 1991). Access to shelter is certainly a key factor determining habitat use, and for $P$. microlepis, a lack of shelter has been shown to reduce densities of this species (Moran \& Sale 1977). While urchin barrens lack the canopy cover provided by kelp habitat, it is likely that the increased access to nest sites where individuals attach their eggs to the substratum, as well as ease of interaction with potential mates in the visually open environment, overcompensates for increases in vulnerability (Tzioumis \& Kingsford 1999). Indeed, it has been demonstrated for other benthic damselfishes that $\mathrm{a}$ visually open environment is preferred to canopy-like situations, as it facilitates detection of ambush predators, leaving individuals with more time to forage and socialise (especially for courtship and mating; Rilov et al. 2007). Urchin barrens are a common habitat in the Sydney area and further south and often occupy more than $50 \%$ of the first $100 \mathrm{~m}$ of the reef in both areas (moving offshore from mean high tide; Underwood et al. 1991, Kingsford \& Battershill 1998). Our survey data indicated that barrens habitat was quite com-

ern part of NSW, with a latitudinal range of approximately $8^{\circ}$. $P$. unifasciata, on the contrary, is more abundant in the northern part of NSW with a latitudinal range of approximately $5^{\circ}$. The results of this study provide evidence that the distribution of specific habitats is ultimately driving present geographic distributions of the 2 focal Parma species. Both lab and field studies indicated that $P$. unifasciata grew more quickly and were shorter lived than $P$. microlepis. On the local scale, where both species coexist, there is a possibility that competition for preferred habitats is determining their distributions.

Parma microlepis presented characteristics of a habitat-specialist species; its abundance was signifi- mon south of the central coast region $\left(33.5^{\circ} \mathrm{S}\right)$ but was very rare north of here, a pattern which is congruent with the distribution of $P$. microlepis. The abundance of both adults and juveniles of $P$. microlepis in less preferable habitats such as fringe or shallows could be explained by resource partitioning due to competitive interactions within this species. This has been observed for other species, such as ponyfishes where the distribution of juveniles among various available habitats has been suggested to reduce competition with other species of this family (Staunton-Smith et al. 1999). Moreover, Buckle \& Booth (2009) found that an ontogenetic shift in diet and gut morphology of this species was significantly correlated with body 


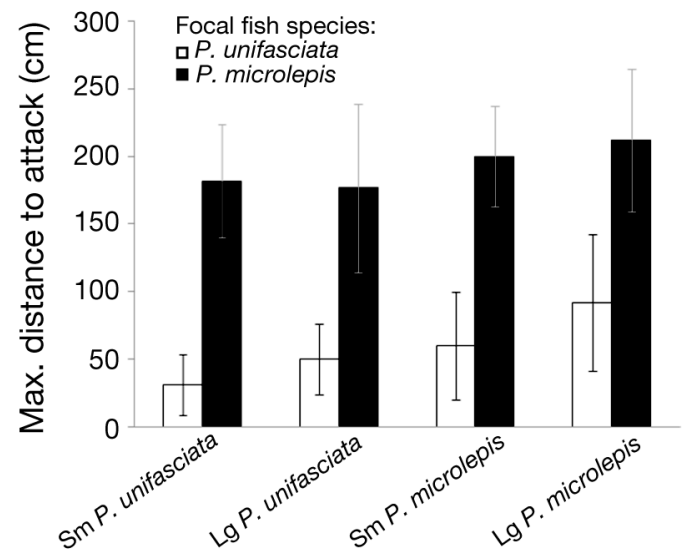

Stimuli fish species and size

Fig. 6. Parma unifasciata and $P$. microlepis. Mean $( \pm \mathrm{SE})$ response of the focal fish to various stimuli fish (total 36 trials). Sm: small; Lg: large

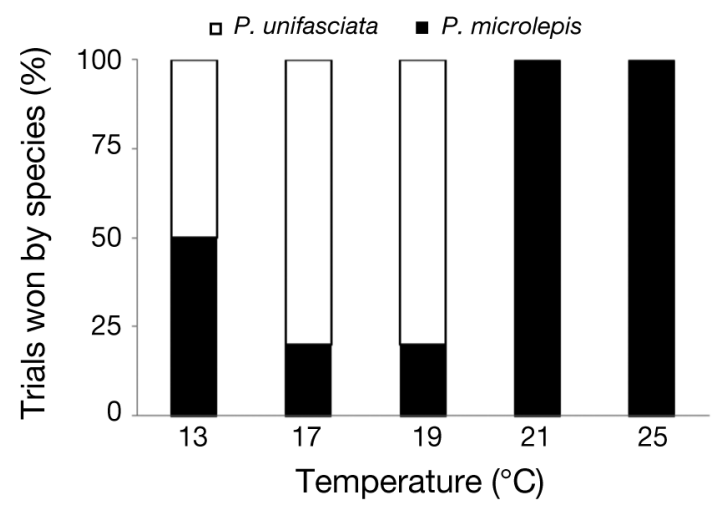

Fig. 7. Parma unifasciata and P. microlepis. Proportional number of wins for both species in lab trials at different temperatures: $13^{\circ} \mathrm{C}: \mathrm{n}=6 ; 17$ and $19^{\circ} \mathrm{C}: \mathrm{n}=5 ; 21$ and $25^{\circ} \mathrm{C}$ : $\mathrm{n}=3$ and 4 , respectively

size, which may indicate reduced resource overlap among conspecifics of different sizes (Werner \& Gilliam 1984).

In contrast, Parma unifasciata may be more of a habitat generalist, using multiple habitats across its range. When available, $P$. unifasciata is most abundant in tufting red algae Pyura habitat, which is very common north of $32^{\circ} \mathrm{S}$, where it accounted for either all or a large proportion of the reef (Underwood et al. 1991, Kingsford \& Battershill 1998). In areas which lack Pyura habitat, P. unifasciata resides in the fringe habitat. The abundance of $P$. unifasciata was low in other available habitats, suggesting that $P$. unifasciata seems to favour relatively shallow waters of the fringe habitat that are rich in foliose algae. These algae are known to dominate the diet of most temperate herbivorous fishes (Jones \& Andrew 1990). The abundance of $P$. unifasciata was low in urchin barrens habitat of the Sydney region (despite this being the most common habitat available). The greater attack distance exhibited by $P$. microlepis, which is highly abundant in this habitat, suggests that it may be relative competitive ability that limits the use of urchin barrens habitat by $P$. unifasciata. Shelter availability is known to be a limiting resource driving competitive interactions between these 2 species (Moran \& Sale 1977).

Where these species co-occur in similar habitat (i.e. urchin barrens) in the Sydney region, it is clear that Parma microlepis is much more aggressive. Given the strong similarity in the ecology of these 2 species, it is possible that the much higher density of $P$. microlepis in barrens habitats is the result of competitive dominance. Research by Johnsson et al. (2000) on brown trout has shown that owners of preferred habitat were more aggressive relative to intruders and attacked intruders sooner than owners of non-preferred habitat. Thus, the high levels of territorial defence by P. microlepis are likely correlated, with this species being a barrens habitat specialist. This competitive dominance may be maintained by enhanced larval supply (relative to other temperate damselfishes for which spawning patterns are similar, Tzioumis \& Kingsford 1995) from the larger biomass of adults, when initial patterns of recruitment remain largely unaltered (a lottery model, sensu Sale 1978b). In addition, due to its long life span, $P$. microlepis has the potential of guarding an established territory for a period 3 times longer than $P$. unifasciata. Laboratory studies on juvenile $P$. microlepis indicated that they outcompeted juvenile $P$. unifasciata at 21 and $25^{\circ} \mathrm{C}$ temperatures, which are found beyond its northern limit $\left(33.5^{\circ} \mathrm{S}\right)$ where average summer temperatures are about $23^{\circ} \mathrm{C}$. Despite this apparent competitive advantage, $P$. microlepis was largely restricted to barrens habitat south of $33.5^{\circ} \mathrm{S}$. Similarly, the northern limit of $P$. unifasciata (about $27^{\circ} \mathrm{S}$ ) is likely to be restricted by the lack of subtidal reefs in this temperatetropical transition zone. Given that $P$. unifasciata outperformed $P$. microlepis regarding growth and competition at lower temperatures $\left(13\right.$ to $\left.17^{\circ} \mathrm{C}\right)$, it is likely that the southern range limit for this species is determined by the interactive effect of habitat preferences and aggressive behaviour by the species. Such interactive effects have been demonstrated to determine the spatial distribution of brown trout (Johnsson et al. 2000).

While the results of this study indicate a pronounced effect of temperature on the growth of both species, there was little, if any, difference in the rela- 
tive shape of these temperature-performance curves, or their modes, which were somewhere between 17 and $21^{\circ} \mathrm{C}$ for both species. Given the high levels of connectivity (no genetic structure) among coastal populations of Parma microlepis (Curley \& Gillings 2009), it is improbable that the coincident thermal optima are simply the result of adaptation to local conditions where fish were collected (assuming similarly open $P$. unifasciata populations). We also noted no differences in growth curves of wild individuals of either species caught at various depths. P. unifasciata did have faster growth rates overall and lower longevity than P. microlepis, which is consistent with the tendency for low-latitude fishes to have shorter life spans (Munday et al. 2008b) relative to higherlatitude ones, which often live much longer and reach larger sizes (Allen 1991). Thus, there is little evidence that adaptation to specific latitudinal and/ or depth thermal regimes is fundamentally driving the observed biogeographic patterns in the distribution of these 2 species.

A typical mechanism of species redistribution is a poleward shift of organisms resulting from the development of novel thermally favourable conditions for their establishment at higher latitudes (Parmesan et al. 1999, Poloczanska et al. 2007). The southeastern coast of Australia is experiencing among the highest rates of warming anywhere on the planet (Ridgway $2007 a, b)$. This warming has already been associated with distribution shifts of many temperate fishes, with non-breeding populations of Parma microlepis now being observed in Tasmania as far south as $42^{\circ} \mathrm{S}$ (Last et al. 2011). These range shifts are facilitated not only by warming waters that allow overwinter survival of post-settlement individuals (a key bottleneck to range expansions; Figueira \& Booth 2010) but also by the strengthening of larval transport mechanisms such as the EAC, the influence of which is being observed further southward than in previous years (Ridgway 2007a).

Our data on optimal growth temperatures do not suggest that these increases in temperature and transport would be any more beneficial in terms of probability of range shifts for either of the 2 Parma species discussed in this study. What is likely to be much more important is how these oceanographic conditions affect habitat and competition between the 2 species. Urchin barrens seems to be key habitat for both species, and future range expansions of $P$. microlepis, but possibly also $P$. unifasciata, will be closely tied to the availability of this habitat. Barrens are created by urchins and limpets; however, gastropods alone cannot maintain barrens (Fletcher
1987, Fletcher \& Underwood 1987). Currently, algal habitats are the most dominant subtidal habitats in Tasmania (Ling 2008, Ling et al. 2009b). However, recent studies have shown that the population of the urchin Centrostephanus rodgersii, the main architect of barrens habitat, is shifting its range southward to the coast of Tasmania, leading to reductions in kelp and increases in urchin barrens habitat (Ling 2008, Ling et al. 2008). Given the tight association of $P$. microlepis with urchin barrens, it is quite likely that this process will serve to expand the range of $P$. microlepis southward.

The fate of Pyura habitat, most commonly occupied by Parma unifasciata, is not as clear as that of urchin barrens. Should its range shift south, displacing any of the other shallow-water habitats, we may see similar shifts in the range of $P$. unifasciata. Even in the absence of this, we might expect $P$. unifasciata to excel under these changing conditions due to its more generalist nature. Habitat generalists are less prone to decline or extinction in response to a habitat disturbance (Kingsford \& Carlson 2010). Habitatgeneralist species have been shown to have higher levels of successful migration from damaged habitats (Feary 2007), thus reducing stress and preventing possible population decline or extinction (Pratchett et al. 2004).

\section{CONCLUSIONS}

The endemic damselfishes Parma unifasciata and P. microlepis are found within only partly overlapping regions over a narrow latitudinal range along the east coast of Australia. Patterns of latitudinal and depth distributions of the 2 study species are strongly tied to habitat availability and potentially to competitive ability, rather than being driven by inherent differences in thermal adaptation. Abundance data indicate that $P$. microlepis is a habitat specialist and is highly dependent on urchin barrens. In contrast, $P$. unifasciata is generally found in shallow habitats characterised by short tufting and foliose red algae. Behavioural experiments demonstrated that the use of some habitats, such as shallow barrens, by $P$. unifasciata could be influenced through competitive exclusion by $P$. microlepis. Despite a competitive advantage in warmer waters, it is likely that $P$. microlepis populations cannot be sustained in the absence of barrens that are mainly formed by the grazing of sea urchins. Similarly, $P$. unifasciata is currently found predominantly in shallow habitats rich in foliose algae, not in the kelp forest dominated by 
Ecklonia radiata and fucoid algae such as Sargassum spp. and Phyllospora comosa stands that are abundant in the south. It is unclear to what extent $P$. unifasciata may be able to capitalise on increases in barrens habitat predicted with warming ocean temperatures in the region. However, our competition data from lab trials would suggest that, if anything, $P$. microlepis holds an advantage at higher temperatures.

Our study is a further demonstration that habitat type is a key factor in determining patterns of distribution and abundance of reef fishes. However, an understanding of the interactive influences of temperature-dependent behavioural interactions and abiotic factors is necessary to provide more refined predictions about range shifts resulting from climate change in marine systems.

Acknowledgements. We thank G. J. Edgar, R. D. StuartSmith and the Reef Life Survey team for providing us with fish count data. Many thanks to the dive buddies who helped us in the field. We thank K. Liversage for revising and proofreading the final version of the manuscript. A special thank you to all at the NSW Fisheries otolith ageing facility for their help with processing and ageing the otoliths. Collections of fish were made under NSW Fisheries Permit F94/146-6.0 to the Centre for Research of Environmental Impact of Coastal Cities. All research was conducted under University of Sydney Animal Ethics Permit L04/52010/1/5308 to W. Figueira. Funding was provided by the Australian Research Council to M.J.K. This is Contribution Number 83 to the SIMS collection.

\section{LITERATURE CITED}

Allen GR (1991) Damselfishes of the world. Mergus Publishers, Melle

> Altmann J (1974) Observational study of behavior sampling methods. Behaviour 49:227-267

> Angilletta MJ Jr, Niewiarowski PH, Navas CA (2002) The evolution of thermal physiology in ectotherms. J Therm Biol 27:249-268

> Biro PA, Post JR, Booth DJ (2007) Mechanisms for climateinduced mortality of fish populations in whole-lake experiments. Proc Natl Acad Sci USA 104:9715-9719

Biro PA, Beckmann C, Stamps JA (2010) Small within-day increases in temperature affects boldness and alters personality in coral reef fish. Proc Biol Sci 277:71-77

Booth DJ, Figueira WF, Gregson MA, Brown L, Beretta G (2007) Occurrence of tropical fishes in temperate southeastern Australia: role of the East Australian Current. Estuar Coast Shelf Sci 72:102-114

Booth DJ, Edgar G, Figueira WF, Jenkins G, Kingsford MJ, Lenanton R, Thresher R (2009) Temperate coastal and demersal fish and climate change. In: Poloczanska ES, Hobday AJ, Richardson AJ (eds) A marine climate change impacts and adaptation report card for Australia. National Climate Change Adaptation Research Facility, Publication 05/09, Hobart. Report No. ISBN 978-1921609-03-9
Buckle EC, Booth DJ (2009) Ontogeny of space use and diet of two temperate damselfish species, Parma microlepis and Parma unifasciata. Mar Biol 156:1497-1505

> Choat JH, Ayling AM (1987) The relationship between habitat structure and fish faunas on New Zealand reefs. J Exp Mar Biol Ecol 110:257-284

> Connell JH (1961) The influence of interspecific competition and other factors on the distribution of the barnacle Chthamalus stellatus. Ecology 42:710-723

> Curley BG, Gillings MR (2009) Population connectivity in the temperate damselfish Parma microlepis: analyses of genetic structure across multiple spatial scales. Mar Biol 156:381-393

> Curley BG, Kingsford MJ, Gillanders BM (2002) Spatial and habitat-related patterns of temperate reef fish assemblages: implications for the design of marine protected areas. Mar Freshw Res 53:1197-1210

> Debenedictis PA (1974) Interspecific competition between tadpoles of Rana pipiens and Rana sylvatica an experimental field study. Ecol Monogr 44:129-151

Edgar GJ, Stuart-Smith RD (2009) Ecological effects of marine protected areas on rocky reef communities - a continental-scale analysis. Mar Ecol Prog Ser 388:51-62

Edwards M, Richardson AJ (2004) Impact of climate change on marine pelagic phenology and trophic mismatch. Nature 430:881-884

- Feary DA (2007) The influence of resource specialization on the response of reef fish to coral disturbance. Mar Biol 153:153-161

> Figueira WF, Booth DJ (2010) Increasing ocean temperatures allow tropical fishes to survive overwinter in temperate waters. Glob Change Biol 16:506-516

> Figueira WF, Biro P, Booth DJ, Valenzuela VC (2009) Performance of tropical fish recruiting to temperate habitats: role of ambient temperature and implications of climate change. Mar Ecol Prog Ser 384:231-239

> Fischer P (2000) Test of competitive interactions for space between two benthic fish species, burbot Lota lota, and stone loach Barbatula barbatula. Environ Biol Fishes 58: 439-446

> Fletcher WJ (1987) Interactions among subtidal Australian sea urchins, gastropods, and algae: effects of experimental removals. Ecol Monogr 57:89-109

Fletcher WJ, Underwood AJ (1987) Interspecific competition among subtidal limpets: effect of substratum heterogeneity. Ecology 68:387-400

- Gagliano M, McCormick MI, Meekan MG (2007) Temperature-induced shifts in selective pressure at a critical developmental transition. Oecologia 152:219-225

> Gillanders BM, Kingsford MJ (1998) Influence of habitat on abundance and size structure of a large temperate reef fish, Achoerodus viridis (Pisces: Labridae). Mar Biol 132: 503-514

Harrington ME, Losey GS (1990) The importance of species identification and location on interspecific territorial defense by the damselfish, Stegastes fasciolatus. Environ Biol Fishes 27:139-146

Helmuth B, Kingsolver JG, Carrington E (2005) Biophysics, physiological ecology, and climate change: Does mechanism matter? Annu Rev Physiol 67:177-201

Hixon MA, Jones GP (2005) Competition, predation, and density-dependent mortality in demersal marine fishes. Ecology 86:2847-2859

Holbrook SJ, Schmitt RJ, Ambrose RF (1990) Biogenic habitat structure and characteristics of temperate reef fish 
assemblages. Aust J Ecol 15:489-503

Holbrook SJ, Kingsford MJ, Schmitt RJ, Stephens JS (1994) Spatial and temporal patterns in assemblages of temperate reef fish. Am Zool 34:463-475

Hurst TP (2007) Causes and consequences of winter mortality in fishes. J Fish Biol 71:315-345

IPCC (Intergovernmental Panel on Climate Change) (2007) Climate Change 2007: synthesis report. Core Writing Team, Pachauri RK, Reisinger A (eds) Contribution of Working Groups I, II and III to the Fourth Assessment Report of the Intergovernmental Panel on Climate Change. IPCC, Geneva

Jobling M (1997) Temperature and growth: modulation of growth rate via temperature change. In: Wood CM, McDonald DG (eds) Global warming: implications for freshwater and marine fish. Cambridge University Press, Cambridge, p 225-253

Johnson CR, Ling SD, Ross J, Shepherd S, Miller K (2005) Establishment of the long-spined sea urchin (Centrostephanus rodgersii) in Tasmania: first assessment of potential threats to fisheries. Project No. 2001/044, Final Report. Fisheries Research and Development Corporation, Hobart

Johnson CR, Banks SC, Barrett NS, Cazassus F and others (2011) Climate change cascades: shifts in oceanography, species' ranges and subtidal marine community dynamics in eastern Tasmania. J Exp Mar Biol Ecol 400:17-32

> Johnsson JI, Carlsson M, Sundstrom LF (2000) Habitat preference increases territorial defence in brown trout (Salmo trutta). Behav Ecol Sociobiol 48:373-377

> Jones GP (1984a) Population ecology of the temperate reef fish Pseudolabrus celidotus (Pisces: Labridae). I. Factors influencing recruitment. J Exp Mar Biol Ecol 75:257-276

Jones GP (1984b) Population ecology of the temperate reef fish Pseudolabrus celidotus (Pisces: Labridae). II. Factors influencing adult density. J Exp Mar Biol Ecol 75: 277-304

$>$ Jones GP (1984c) The influence of habitat and behavioral interactions on the local distribution of the wrasse Pseudolabrus celidotus. Environ Biol Fishes 10:43-58

> Jones GP (1986) Food availability affects growth in a coral reef fish. Oecologia 70:136-139

> Jones GP, Andrew NL (1990) Herbivory and patch dynamics on rocky reefs in temperate Australasia: the roles of fish and sea urchins. Aust J Ecol 15:505-520

> Jones GP, McCormick MI, Srinivasan M, Eagle JV (2004) Coral decline threatens fish biodiversity in marine reserves. Proc Natl Acad Sci USA 101:8251-8253

Kesby C, McKinnon J (2009) Otolith processing protocol. NSW Department of Industry and Investment, Sydney

> Keser M, Swenarton JT, Foertch JF (2005) Effects of thermal input and climate change on growth of Ascophyllum nodosum (Fucales, Phaeophyceae) in eastern Long Island Sound (USA). J Sea Res 54:211-220

Kimura DK (1980) Likelihood methods for the von Bertalanffy growth curve. Fish Bull 77:765-776

Kingsford MJ, Battershill C (1998) Studying temperate marine environments: a handbook for ecologists. Canterbury University Press, Christchurch

> Kingsford MJ, Carlson IJ (2010) Patterns of distribution and movement of fishes, Ophthalmolepis lineolatus and Hypoplectrodes maccullochi, on temperate rocky reefs of south eastern Australia. Environ Biol Fishes 88:105-118

Kingsford MJ, Schiel DR, Battershill CN (1989) Distribution and abundance of fish in a rocky reef environment at the subantarctic Auckland Islands, New Zealand. Polar Biol 9:179-186

Kritzer JP (2002) Variation in the population biology of stripey bass Lutjanus carponotatus within and between two island groups on the Great Barrier Reef. Mar Ecol Prog Ser 243:191-207

Last PR, White WT, Gledhill DC, Hobday AJ, Brown R, Edgar GJ, Pecl G (2011) Long-term shifts in abundance and distribution of a temperate fish fauna: a response to climate change and fishing practices. Glob Ecol Biogeogr 20:58-72

> Ling SD (2008) Range expansion of a habitat-modifying species leads to loss of taxonomic diversity: a new and impoverished reef state. Oecologia 156:883-894

> Ling SD, Johnson CR, Frusher S, King CK (2008) Reproductive potential of a marine ecosystem engineer at the edge of a newly expanded range. Glob Change Biol 14: 907-915

Ling SD, Johnson CR, Frusher SD, Ridgway KR (2009a) Overfishing reduces resilience of kelp beds to climatedriven catastrophic phase shift. Proc Natl Acad Sci USA 106:22341-22345

> Ling SD, Johnson CR, Ridgway K, Hobday AJ, Haddon M (2009b) Climate-driven range extension of a sea urchin: inferring future trends by analysis of recent population dynamics. Glob Change Biol 15:719-731

- Malcolm HA, Gladstone W, Lindfield S, Wraith J, Lynch TP (2007) Spatial and temporal variation in reef fish assemblages of marine parks in New South Wales, Australiabaited video observations. Mar Ecol Prog Ser 350: $277-290$

> Moran MJ, Sale PF (1977) Seasonal variation in territorial response, and other aspects of ecology of Australian temperate pomacentrid fish Parma microlepis. Mar Biol 39: 121-128

> Munday PL, Jones GP, Pratchett MS, Williams AJ (2008a) Climate change and the future for coral reef fishes. Fish Fish 9:261-285

Munday PL, Kingsford MJ, O'Callaghan M, Donelson JM (2008b) Elevated temperature restricts growth potential of the coral reef fish Acanthochromis polyacanthus. Coral Reefs 27:927-931

> Parmesan C, Ryrholm N, Stefanescu C, Hill JK and others (1999) Poleward shifts in geographical ranges of butterfly species associated with regional warming. Nature 399:579-583

Perry AL, Low PJ, Ellis JR, Reynolds JD (2005) Climate change and distribution shifts in marine fishes. Science 308:1912-1915

Poloczanska ES, Babcock RC, Butler A, Hobday A and others (2007) Climate change and Australian marine life. In: Gibson RN, Atkinson RJA, Gordon JDM (eds) Oceanography and marine biology: an annual review, Vol 45, Taylor \& Francis, South Yarra, p 407-478

Pratchett MS, Wilson SK, Berumen ML, McCormick MI (2004) Sublethal effects of coral bleaching on an obligate coral feeding butterflyfish. Coral Reefs 23:352-356

Ridgway KR (2007a) Long-term trend and decadal variability of the southward penetration of the East Australian Current. Geophys Res Lett 34, L13613, doi: 10.1029/ 2007GL030393

Ridgway KR (2007b) Seasonal circulation around Tasmania: an interface between eastern and western boundary dynamics. J Geophys Res 112, C10016, doi: 10.1029/ 2006JC003898 
Rilov G, Figuiera WF, Lyman SJ, Crowder LB (2007) Complex habitats may not always benefit prey: linking visual field with reef fish behavior and distribution. Mar Ecol Prog Ser 329:225-238

Roessig JM, Woodley CM, Cech JJ Jr, Hansen LJ (2004) Effects of global climate change on marine and estuarine fishes and fisheries. Rev Fish Biol Fish 14:251-275

Sale PF (1978a) Chance patterns of demographic change in populations of territorial fish in coral rubble patches at Heron reef. J Exp Mar Biol Ecol 34:233-244

Sale PF (1978b) Coexistence of coral reef fishes a lottery for living space. Environ Biol Fishes 3:85-102

Staunton-Smith J, Blaber SJM, Greenwood JG (1999) Interspecific differences in the distribution of adult and juvenile ponyfish (Leiognathidae) in the Gulf of Carpentaria, Australia. Mar Freshw Res 50:643-653

Tait RV (1981) Elements of marine ecology, 3rd edn. Butterworths, London

Thompson SM, Jones GP (1983) Interspecific territoriality and competition for food between the reef fishes Forsterygion varium and Pseudolabrus celidotus. Mar Biol 76:95-104

Tzioumis V, Kingsford MJ (1995) Periodicity of spawning of

Editorial responsibility: Charles Birkeland,

Honolulu, Hawaii, USA two temperate damselfishes: Parma microlepis and Chromis dispilus. Bull Mar Sci 57:596-609

- Tzioumis V, Kingsford MJ (1999) Reproductive biology and growth of the temperate damselfish Parma microlepis. Copeia 348-361

Underwood AJ (1997) Experiments in ecology: their logical design and interpretation using analysis of variance. Cambridge University Press, Cambridge

Underwood AJ, Kingsford MJ, Andrew NL (1991) Patterns in shallow subtidal marine assemblages along the coast of New South Wales. Aust J Ecol 16:231-249

Valiela I (1995) Marine ecological processes. Springer, New York, NY

Walther GR, Post E, Convey P, Menzel A and others (2002) Ecological responses to recent climate change. Nature 416:389-395

Wernberg T, Bayden RD, Moore PJ, Ling SD and others (2011) Impacts of climate change in a global hotspot for temperate marine biodiversity and ocean warming. J Exp Mar Biol Ecol 400:7-16

Werner EE, Gilliam JF (1984) The ontogenetic niche and species interactions in size structured populations. Annu Rev Ecol Syst 15:393-425

Submitted: June 11, 2012; Accepted: February 4, 2013 Proofs received from author(s): May 27, 2013 